\title{
A new sand and gravel map for the UK Continental Shelf to support sustainable planning
}

\author{
Tom Bide, ${ }^{A}$, tode@bgs.ac.uk, Peter Balson, ${ }^{B}$ Joseph Mankelow ${ }^{A}$, and lan Selby, ${ }^{C}$. \\ ${ }^{A}$ British Geological Survey, Keyworth, Nottinghamshire, NG123HZ \\ B independent consultant \\ C The Crown Estate, 16 New Burlington Place, London, W1S $2 \mathrm{HX}$
}

\section{Highlights}

- The first map depicting the marine sand and gravel resources of the UK continental shelf has been developed

- Spatial data developed using a constant methodology is needed for marine spatial planning as required by EU regulations.

- This dataset is being used to ensure minerals are protected and adequately considered in the planning process.

\begin{abstract}
The planning framework for the UK Continental Shelf (UKCS) is undergoing significant change. An integrated plan-led process, similar to that undertaken onshore, is now being applied offshore. It is vital that marine mineral resources are adequately considered in this process. In order to facilitate this, the first ever sand and gravel mineral resources map of the entire UKCS has been created.

Offshore resources have been defined by integrating geological mapping data and the British Geological Survey's extensive collection of core, sea bed sample and geophysical records. A spatial model has been developed that highlights the location and likely composition of sand and gravel deposits with the results undergoing geological review to ensure different sea-bed features have been adequately represented. Results are presented as a series of four maps covering the entire UKCS.

With increasing pressure on marine space it is important to balance the competing demands and needs from different use sectors. Identification of the distribution of sand and gravel resources at a national scale and presentation in a consistent fashion allows planners to adequately consider minerals in the planning process and permits more effective and sustainable sea-use management strategies to be developed.
\end{abstract}

Keywords: Spatial planning, aggregates, minerals, dredging, mineral safeguarding. 


\section{Introduction}

Sand and gravel deposits consist of accumulations of durable rock fragments and mineral grains that have been derived from the weathering and erosion of bedrock, mainly by glacial and fluvial processes, but also by marine and wind erosion. On the UKCS most economic resources of sand and gravel are composed of particles that are rich in silica (quartz, quartzite and flint).

Most offshore sands and gravels on the UKCS have similar origins to their land-based equivalents. Many of these marine aggregate resources are relict deposits that were formed during times when the sea level was much lower than at present. During these periods large parts of the modern sea bed were exposed, glaciated or crossed by major river systems. In contrast to land-based deposits, deposits can also be formed where modern marine processes have concentrated sand and gravel into surface features, such as sand banks.

Marine sands and gravels form an important part of the supply chain of construction materials. The UK has one of the largest construction aggregate dredging industries in the world providing $24 \%$ (10.2 million tonnes) of the UK's annual consumption of sand and gravel in 2012 (Bide et al., 2014). The supply of marine sand and gravel is especially important in major urban centres, such as London, where $50 \%$ of the sand and gravel required by construction projects is supplied from offshore (The Crown Estate, 2014). Here it can be landed at city wharves very near to the market, reducing costs and energy intensive road transportation associated with land-based resources.

Demand for these offshore mineral resources is unlikely to decline in the future as the UK develops. Possible major infrastructure projects such as new power stations and transportation hubs all need large volumes of sand and gravel. The effects of climate change will also cause an increased demand as more material is required for coastal defences. These high levels of demand combined with ever increasing competition for uses and designation of the sea bed from, for example, renewable energy installations, fishing, pipelines, marine protected areas, etc. all have the potential to restrict supply. As a result it is vital to ensure offshore resources are planned sustainably and effectively, utilising the best available information.

A lack of suitable spatial data for inclusion in the planning process for marine mineral resources has necessitated the creation of marine mineral resource maps and corresponding digital data. The maps and data created by this research contain comprehensive information on the location and properties of offshore sand and gravel resources. This information will aid in the sustainable use of, and facilitate the planning for, these materials (Bide, et al., 2013). 


\subsection{UK planning for marine sand and gravel}

Historically, there has been limited marine planning which has been approached on a sectoral basis, considering planning issues at the level of individual project or permits. For example, in the UK, for over 20 years, some sectors have been applying an Environmental Impact Assessment (EIA)-based approach voluntarily. This has been the case for marine dredging. This has meant that decisions were made in isolation sometimes leading to conflict between different sectors utilising the sea bed (e.g. fisheries, mineral extraction, energy, infrastructure). The impact of different economic sectors and marine protected areas on one another and the resultant conflict, as well as a lack of communication between responsible bodies, indicated a clear need for a more integrated spatial planning framework for the use of marine space (Douvere, 2008). Historically, such communication was the responsibility of industry bodies. In the UK some sectors, such as marine aggregate extraction, developed best practice guidance and liaison protocols (for example, in relation fisheries and archaeological finds) to mitigate such conflicts as much as possible (Newell and Woodcock, 2013).

Marine spatial planning has evolved and grown as a concept over the last 15 years. Initially it involved the creation of marine protected areas where the main purpose was for the protection of ecosystems against anthropogenic pressures as, for example, the Great Barrier Reef or the Florida Keys. In the UK, consideration of the protection of the marine environment in this way began with the UK Habitats Directive 1994, (Statutory Instruments 1994 No.2716) following on from the EU Habitats Directive of 1992 (Council Directive 92/43/EEC). More recently, however, it has begun to be used where there are multiple (potentially conflicting) uses of marine space with great economic as well as environmental value, that need to be carefully balanced and managed to avoid potential conflict, as for example in the North Sea (Douvere, 2008).

In the UK the process of marine spatial planning began with the Marine and Coastal Access Act 2009 (HM Government, 2009), the Marine (Scotland) Act 2010 (Scottish Government, 2010) and the Marine Act (Northern Ireland) 2013, which introduced a new system for marine planning and licensing. The Acts are very relevant to mineral resources, not only altering the way exploration and extraction are licensed but also representing a significant change from a sectoral-based permit system to a more holistic plan-led one. For England a new body, the Marine Management Organisation (MMO), has been created and tasked with formulating spatial plans and associated policies. The Scottish Government, Welsh Government and Department of Environment for Northern Ireland are responsible for this in their respective marine areas.

The Acts paved the way for the UK-wide marine policy statement announced in March 2011 (HM Government et al., 2011). This document set the framework for the preparation of marine plans in the UK under the guidance of the $\mathrm{MMO}$ and respective counterparts for Wales, Scotland and Northern Ireland. These plans, being developed at the time of writing, 
will provide detailed, coherent policy and associated spatial guidance for marine activities. With regard to marine sand and gravel the marine policy statement specifically states that plans should ensure provision for the long-term supply of sand and gravel and take into account the need to safeguard mineral resources from sterilisation by other forms of development. This is explained in much more detail in section 3.5.5 and 3.5.6 of the policy document (HM Government et al., 2011).

Consideration of minerals issues in spatial planning is not new in the UK. Protection of mineral resources to ensure adequate and steady supply is already undertaken in the UK onshore planning system. The National Planning Policy framework (NPPF) contains several specific policies regarding minerals issues (DCLG, 2012).

The marine policy statement also recognises that minerals can only be worked where they occur, which is a key difference between minerals planning and many other forms of landuse planning. As a result, in order to secure the adequate and steady supply of marine sand and gravel there is a need to ensure that sterilisation of mineral resources is adequately considered during the determination of applications for other forms of offshore development, such as wind farms, oil and gas platforms, ports, pipelines and the laying of cables. Such developments if located on, or near, mineral resources will prohibit their future extraction.

The process of mineral safeguarding is one method to prevent such sterilisation. Safeguarding forms a key part of onshore spatial minerals planning (DCLG, 2012), and as one of the goals of the new marine planning system is to better align onshore and offshore planning, the principles of mineral safeguarding can be applied offshore. Consequently mineral safeguarding policies have been included in the first marine spatial plan for the East Coast (MMO 2014).The mineral safeguarding process involves recognising that a mineral resource is present by using spatial minerals information to formulate suitable polices and then to appropriately manage any planning applications for development to ensure that the mineral resource is not needlessly sterilised (Wrighton et al., 2011).

\subsection{International approaches to spatial planning for marine sand and gravel}

Marine spatial planning is now a well-established process (Douvere, 2008). However, consideration of issues regarding offshore sand and gravel resources are often poorly represented in the plans of many responsible bodies. Typically this is due to the small-scale nature of the marine sand and gravel industry in many countries. The inclusion of mineral related policies in the UK marine policy statement and prominence given in MMO marine plans to offshore sand and gravel resources exhibits the importance of the marine aggregate sector in the UK and the significance it has in UK aggregates supply, when compared to other nations. 
One of the first significant steps in marine spatial planning in the EU was the adoption of an integrated maritime policy by the European Parliament in 2007 (European Parliament, 2007; Hull, 2013). This policy aims to increase coordination between EU member states by the introduction of different key policy areas. This has relevance to marine sand and gravel extraction as sustainable growth in marine industries, termed 'blue growth', has been highlighted as one of these key policy areas (European Parliament, 2012). The integrated maritime policy paved the way for The Marine Strategy Framework Directive (Directive 2008/56/EC), which set the agenda for marine spatial planning in the UK. The Directive prescribes an ecosystems-led approach with the aim of lowering pressure on natural marine resources and marine ecological services (European Parliament, 2008). This is a high level document outlining the need for EU- wide protection of marine ecosystems and does not specifically mention any industrial sector, but focuses on how to mitigate against damage. This is a common theme in many marine policy documents in that dredging for marine sand and gravel is only mentioned in relation to the potential damaging effects of dredging as opposed to the importance of these natural resources in their own right. This is the case for Portugal's spatial marine plan, (Carneiro, 2007) and for regional marine spatial plans for the USA (NOAA, 2014). However, for the USA and Portugal, unlike the UK, marine aggregates do not form a significant part of the supply chain for construction material in plan areas, so there is less need for consideration.

National marine plans are often at a high level and do not go into detail with regard to specific industries. Although there are currently no marine aggregate extraction sites in Scottish waters, Scotland's marine plan is more like that of England's with regard to aggregates. It contains policies safeguarding potential areas of aggregate resources from potential conflicting development and which minimise the impact of aggregate extraction on the marine environment in an attempt to balance both economic and environmental priorities (Scottish Government, 2015).

Whilst not making specific references to marine aggregates, there are many aspects of EU initiatives that impact on the extraction of marine sand and gravel in the UK. For example the implementation of integrated coastal zone management (ICZM) initiated by an EU communication (European Parliament, 2000) and subsequently adopted by Directive 2014/89/EU (European Parliament, 2014) for example advocates the use of spatial planning of the onshore and offshore coastal zones, setting a precedent for linking the wellestablished onshore planning legislation with the less well established offshore planning legislation in the UK.

The need to balance protection of the marine environment with economic growth has driven the development of spatial marine plans in many EU countries, some of the most developed being Germany, Belgium, the Netherlands and the UK. There are many different approaches that can be taken for plan development. Belgium has one of the most advanced marine spatial plans within the EU, and has produced very prescriptive polices for the use of 
marine space. This is delivered via a plan designating zones for specific uses, including aggregates (C-SCOPE, 2011). Like the UK, Belgium has applied a land-use approach to the marine environment via a spatial management policy for the Belgian sector of the North Sea. It also, like the UK, places a high importance on economic factors, seeking to balance ecosystems-based management against commercial use of marine space.

Another country that has an established marine sand and gravel extraction industry, principally for material for coastal defence, and has implemented marine spatial planning is the USA. The USA has established a National Policy for the Stewardship of the Ocean. The resultant executive order, Our Coasts and the Great Lakes (US Government, 2010), sets out overarching guidelines for the implementation of marine plans. Like EU initiatives, the USA policy outlines broad aims and goals for the management of the marine environment, with themes covering promotion of economic growth and protection of ecosystems. These themes have implications for mineral extraction but specific sectors are not legislated for in detail (National Ocean Council, 2013). Implementation for marine planning is the responsibility of seven specific regions, which have produced their own plans. These are ecosystems-led and make very little mention of specific industries exploiting the marine environment, such as marine aggregate extraction. This is a similar theme to the marine plans of other countries, for example New Zealand's, where the importance of mineral extraction is discussed but specific policies have not been formulated (Bess, 2010).

\subsection{Marine minerals spatial information}

Spatial planning for minerals is constrained by the fact that these resources can only be extracted where they naturally occur. As a result accurate spatial data is required on the location and properties of mineral resources for planning to be effective. This need for data has driven the creation of a mineral resources dataset for the UK continental shelf, the primary objective of which is to provide baseline data that will assist long-term planning for minerals supply.

As well as providing useful information to planners, the UK marine sand and gravel dataset will prove valuable to a much wider audience, including the minerals industry, other users of the sea bed (oil, gas, renewable energy industries) together with environmental and regulatory bodies and the general public. The UK marine sand and gravel dataset has been produced to a common standard and at a common scale on a seamless national level and is easily accessible in a digital format. Critically, the dataset will help to ensure adequate supplies of marine sand and gravel are conserved for future generations.

The only other countries to date that have produced maps of offshore aggregate resources (as opposed to charts showing current licensed areas of extraction) are Germany, France and The Netherlands. These countries all have a marine sand and gravel extractive industry and a need for material for coastal defence. The resource maps of France and Germany rely on existing mapping of sea bed sediments to infer resource potential, i.e. gravelly deposits 
on the sea bed are assumed to represent potential sand and gravel resources. It is also assumed that sediments of similar properties will continue at depth and limited deposit thickness information is incorporated.

Maps for German waters, produced by BGR (the Federal Geological Survey of Germany), show gravel resources for all of the German EEZ (Exclusive Economic Zone) to a depth of $0.2 \mathrm{~m}$ with data for deeper deposits in selected areas (BGR, 2011). Also thematic maps have been produced depicting sand suitable for beach recharge and land reclamation applications for an area north of the East Frisian Islands (BGR, 2013).

The marine aggregate maps for France, produced by IFREMER (French Research Institute for Exploitation of the Sea), are similar to the BGR maps. Mapped geological features and bedforms (such as sand banks) as well as thicknesses from shallow geophysical surveys have been used to infer the presence of marine aggregate resources. As well as these small scale maps IFREMER have also produced maps showing the potential for marine sand and gravel resources for limited areas of interest. These classify sediments into a 1-4 scale of unworkable to prospective, using a combination of thicknesses and geological interpretation of suitability for aggregates based on core data (IFREMER 2007).

In the Netherlands, TNO (The Netherlands Organisation for Applied Scientific Research) have utilised a different approach to create maps of offshore sand resources. A detailed 3D model of sand and gravel resources off the coastline of the Netherlands has been produced. This is based on a 3D parameterised model of sand and gravel resources covering the area out to 12 nautical miles from the -20 m bathymetric contour (TNO, 2012). It also facilitates accurate determination of volumes and properties of sand and gravel resources at a local scale. Density of data for this type of model development needs to very high but, where available, can produce the most reliable and detailed sand and gravel resource information. Such data is absent over large areas of the UK continental Shelf (UKCS) and indeed for much of the North Sea (except for localised areas).

\section{Methodology}

The UK marine sand and gravel dataset consists of digital spatial data and a series of maps, generated from the data, covering the entire UKCS. The mineral resources that have been defined show the areas within which potentially workable minerals may occur. A mineral resource ${ }^{1}$ is defined as a natural concentration or occurrence of material of intrinsic economic interest in, or on the Earth's crust in such form, quality and quantity that there are reasonable prospects for eventual economic extraction (PERC, 2013). What may be of economic interest changes over time, as markets decline or expand, product specifications

\footnotetext{
${ }^{1}$ This dataset does not show mineral reserves. A mineral reserve is defined as that part of a mineral resource which has been fully evaluated and is commercially viable to work (PERC, 2013). In the context of UK planning, the term mineral reserve should strictly be further limited to those minerals for which a valid license for extraction exists (i.e. permitted reserves). Without a valid planning consent no mineral working can take place.
} 
change, recovery technology is improved or more competitive sources become available. Economic constraints of particular importance to marine aggregates extraction include the depth below sea level at which deposits occur (currently most vessels operating in UK waters are able to dredge a maximum depth of around 30-50 metres) and the distance from the coast. Such economic constraints are difficult to predict when taking a long term planning view, the specification of dredging vessels is something that is constantly changing. More modern aggregate dredging vessels currently being commissioned can extract material over 60 metres deep and cover greater distances more economically due to more efficient engines than many in the currently operating UK fleet.

As the map has been produced with the safeguarding of mineral resources for potential future use as a primary aim these economic factors have not been considered. This is in accordance with the principles of mineral safeguarding to ensure that areas that may not be considered economic now are not sterilised by other forms of sea floor development, such as windfarms or pipelines. Likewise changing markets in both the UK and the wider North Sea area combined with a growing need for material for coastal defence and infrastructure projects is likely to lead to large volumes of material being required in new areas outside of those traditionally reliant on marine aggregates.

For similar reasons no consideration has been given to environmental constraints, such as designated areas or areas close to at risk coastlines. However, for any future studies considering these types of economic or environmental constraints the information contained in the map forms an essential baseline.

\subsection{Datasets used to define The UKCS marine sand and gravel resources}

To ensure the best results care was taken to include the most up-to-date and comprehensive sources of data. Due to the national extent of the map, data sources with seamless national or regional coverage were of most use but, where available, data sources with more limited coverage were also used. Principal data sources used were:

- BGS's legacy dataset of sea bed sediment samples (over 32 000), cores (over 5 500), geophysical records (over $350000 \mathrm{~km}$ of seismic records) and 165 offshore geological maps (previously published as a series of 1:250 000 scale geological maps covering sea bed sediments, Quaternary geology and bedrock geology).

- BGS's digital dataset of sea bed sediments (DigSBS) (British Geological Survey, 2011)

- Data collected as part of Marine Aggregates Levy Sustainability Fund (MALSF) ${ }^{2}$ research, principally from the Regional Environmental Characterisation (REC) ${ }^{3}$ reports.

\footnotetext{
2 The MALSF was a fund, supported by a levy on the aggregates industry with the aim of minimising the demand for primary aggregates, promoting environmentally friendly extraction and transport, and reducing the effects of local aggregate extraction.

3 The REC surveys were a series of regional surveys, funded by the MALSF, to develop understanding of Britain's submerged habitats and heritage and to enable broad-scale characterisation of the sea bed.
} 
- Bathymetric data.

- Previous work on marine sand and gravel resources commissioned by The Crown Estate.

- Data provided by the marine aggregates dredging industry.

Data sources were divided into two principal types. Those with national or near national coverage, that would be included in a GIS model used to define sand and gravel resources, and those that would be used to truth and add value through geological interpretation of the model outputs to ensure accurate and consistent output. The model inputs consisted of a wide range of data, much of which is spatially variable and not always available in a consistent and convenient form. All data sources were integrated into a GIS to provide the best possible information on aggregate locations and properties on a national scale.

\subsection{Modelling of mineral resource areas}

The dataset has been created using a thematic approach to identify areas of sediment with potential for aggregate resources. These areas have then been parameterised to determine the type of aggregate resources present. The modelling process, integrating such a diverse range of data from multiple sources, was a complex task. To ensure maximum clarity and transparency so that the final data set can be easily integrated into the planning process, a decision flow was developed and used to identify areas of resources (Figure 1). This identified various steps and gateways defining the properties of resources which either eliminated unprospective areas of sea bed or categorised sediments based on their properties for aggregate potential. 


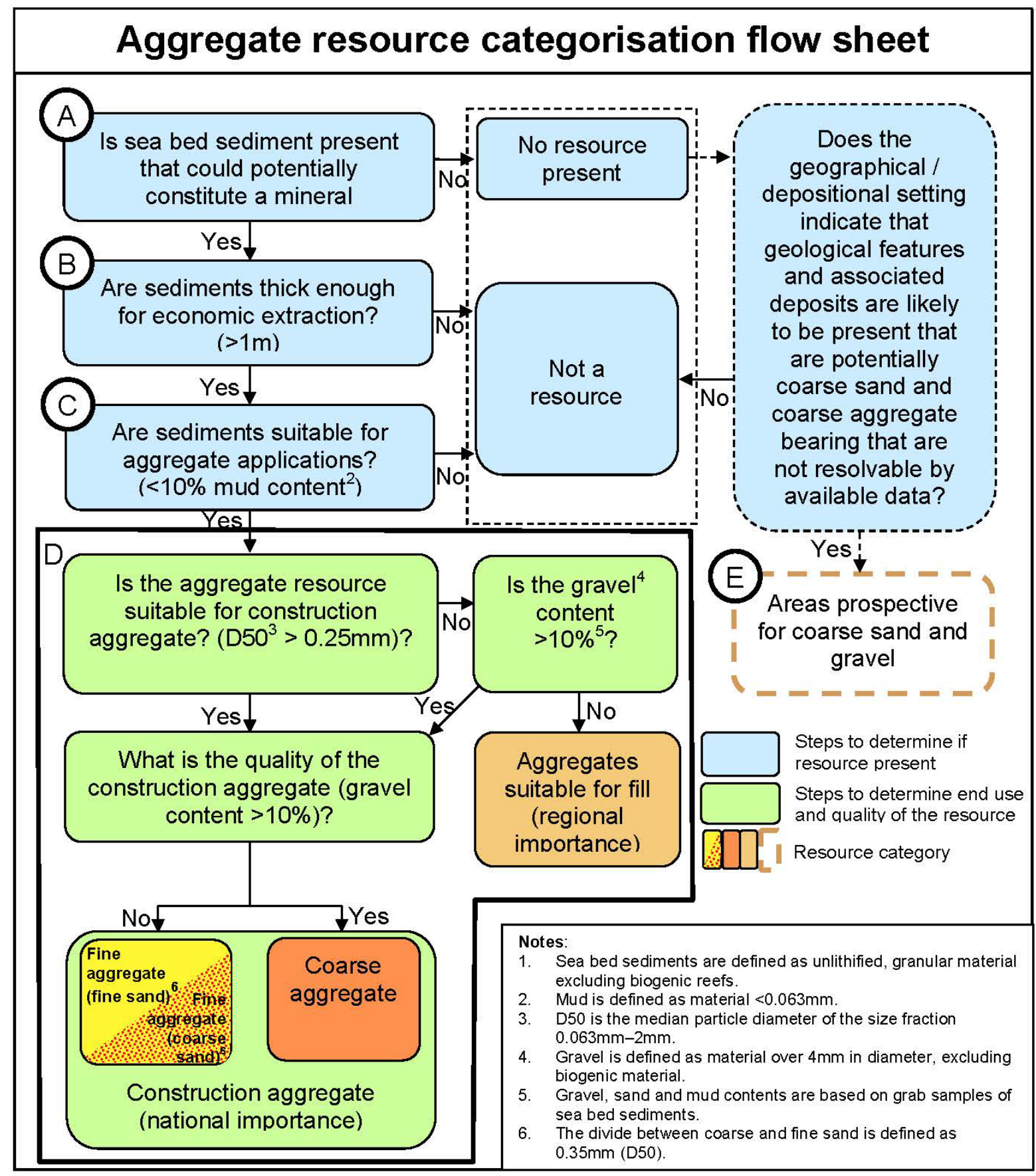

Figure 1. Marine sand and gravel resource categorisation flow sheet. Letters $A$ to $E$ refer to steps in the process described in the text.

Figure 1 explains the process by which the maps were constructed, and is designed to help stakeholders gain an understanding of precisely what is represented on the maps. It also provides transparency to the process of data analysis. This is very important from a planning point of view which requires evidence-based, robust and transparent data for inclusion in the planning process. Five steps are identified in the process, labelled A to E on Figure 1. 


\section{Step A}

The first step in ascertaining the presence of mineral resources was to eliminate all areas that do not contain suitable sediment. This was done using BGS's map of sea bed sediments, the DigSBS dataset (British Geological Survey, 2011) (Figure 2). This dataset depicts the distribution of sea bed sediment types according to the Folk classification (Folk, 1954). This provided a rapid way to identify the composition of the sea bed sediments to determine if they are suitable as an aggregate resource, at a scale suitable for a regional overview. Areas of no resource are where sea bed sediments are absent, or do not contain suitable clastic sediments. For example, areas of bedrock and biogenic reefs. All other areas were considered as having potential for sand and gravel resources.

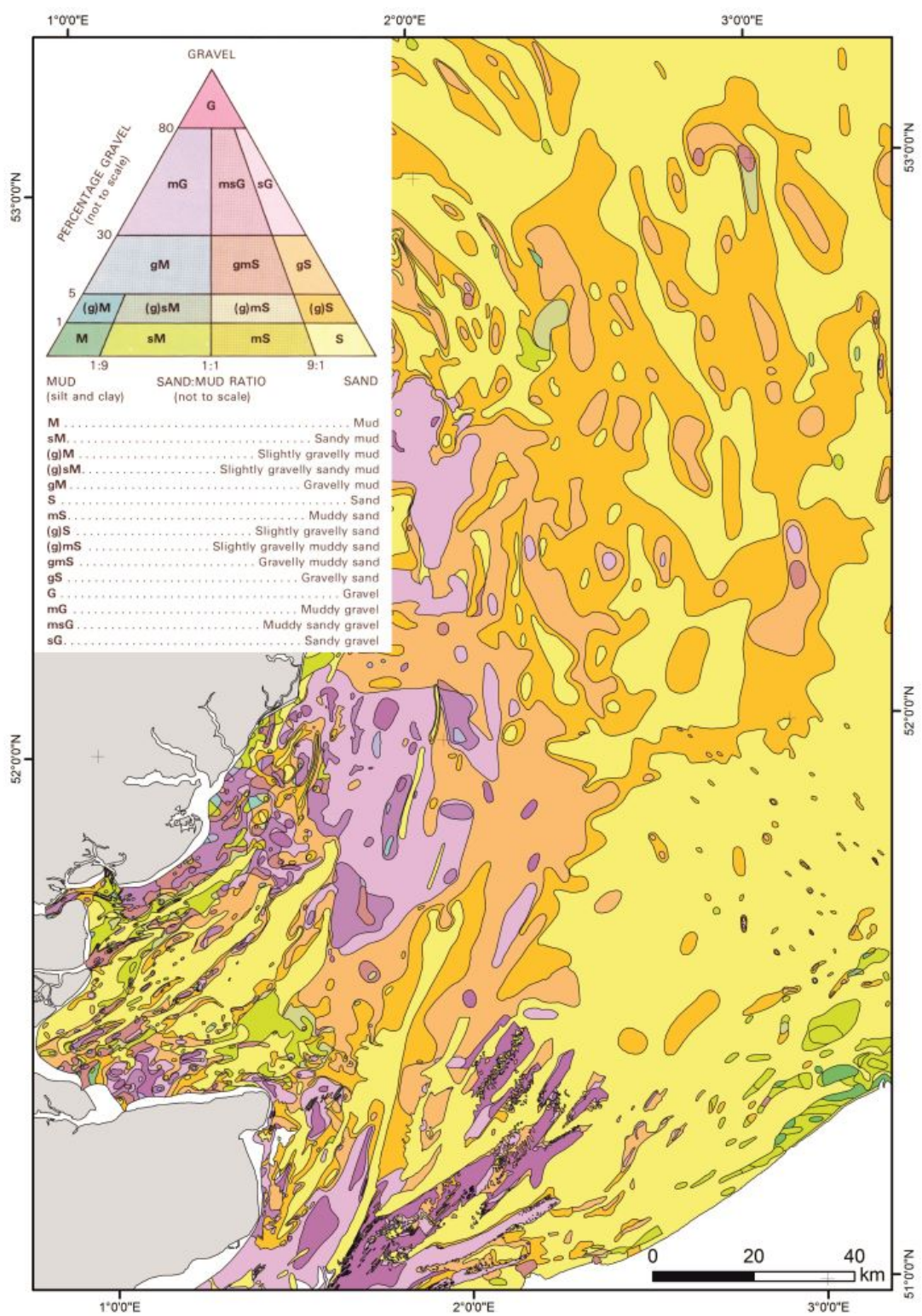

Figure 2. An example of the DigSBS250 dataset. 


\section{Step B}

The next step was to determine if there is sufficient thickness of sediment to be a potential aggregate resource. Many areas of the UKCS have a thin veneer of coarser material overlying bedrock or fine-grained glacial deposits. These gravel lag deposits are not prospective for aggregates as they are too thin to economically extract and need to be differentiated from more prospective thicker sands and gravels. After consultation with industry it was decided that an economic resource would require at least one metre thickness of sediment. This step required a dataset of sediment thickness over the entire UKCS. Unfortunately such a dataset did not exist and so a combination of data was used to build up a nationwide thickness dataset. This is based predominantly on existing BGS mapping of sediment (Holocene) thickness in areas where available (Figure 3). Data from these maps was enhanced with the use of maps showing the distribution of various bedforms such as sandwaves and sand banks, which have been used as a proxy for sediment thickness (Figure 4). For example the presence of a sand bank was used to infer a thickness of over 10 metres of sediment, whereas a sandwave field was used to infer a thickness of 2 5 metres.

If no pre-existing maps were available digital bathymetric data was used and polygons digitised around obvious major bedforms and similar bathymetric features. To fill any gaps in the dataset additional geological interpretation, from cores and seismic records, was used to create a point dataset of sediment thickness, from which simple digital sediment thickness models were built. The point data was interpolated using the Inverse Distance Weighted ${ }^{4}$ (IDW) technique to produce a grid, with a $1 \mathrm{~km}$ cell size. The grid was then reclassified into appropriate categories and converted to polygons (Figure 5).

\footnotetext{
${ }^{4}$ IDW is an interpolation technique that uses the assumption that things close to one another are more alike than those further apart. To predict unknown values the nearest known values are used and weighted according to distance from the point in question.
} 


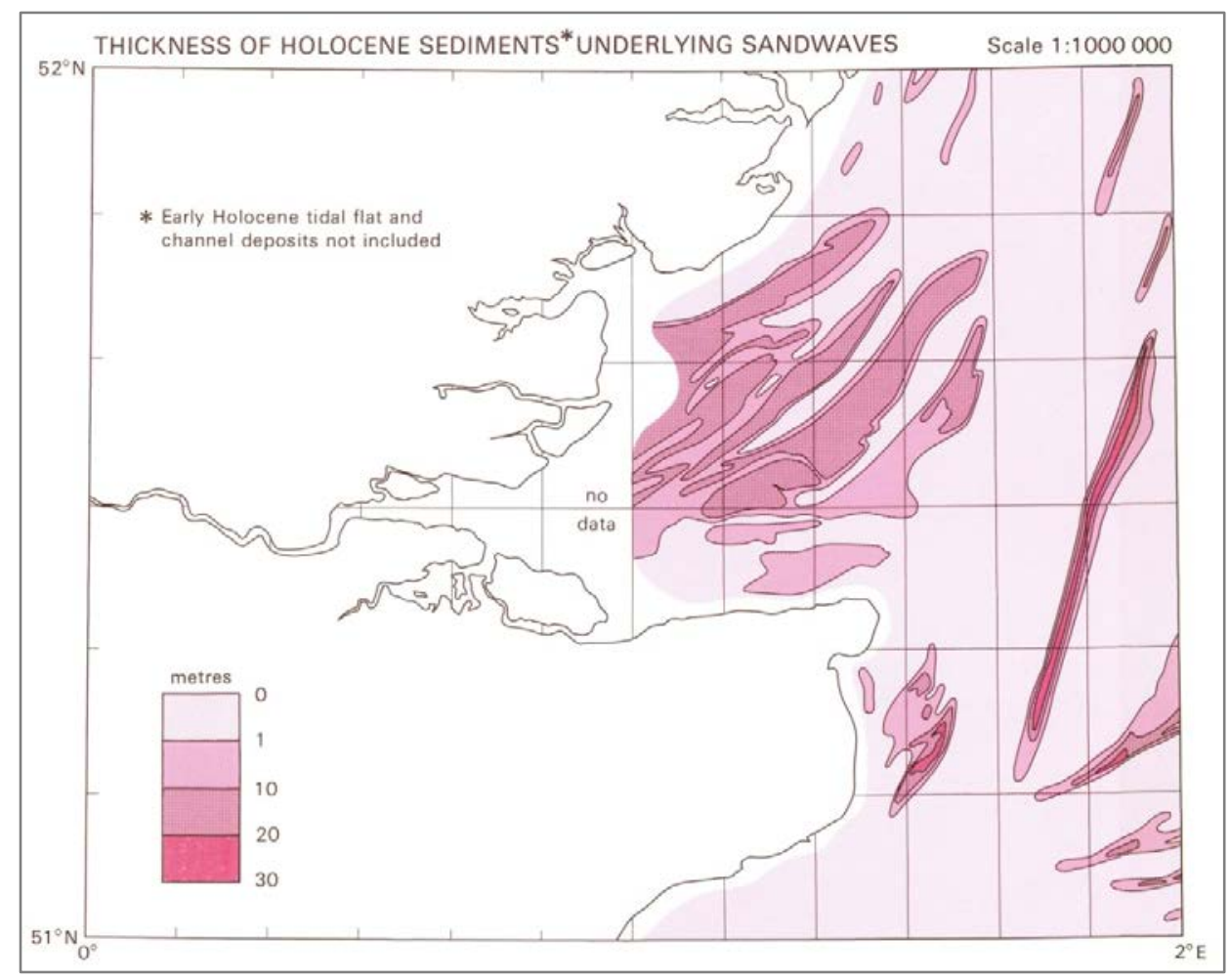

Figure 3. Example of a Holocene sediment thickness map taken from the BGS 1:250 000 scale map series (from 1:250 000 Sea Bed sediments and Quaternary geology map for the Thames Estuary; Balson and D'Olier, 1990).

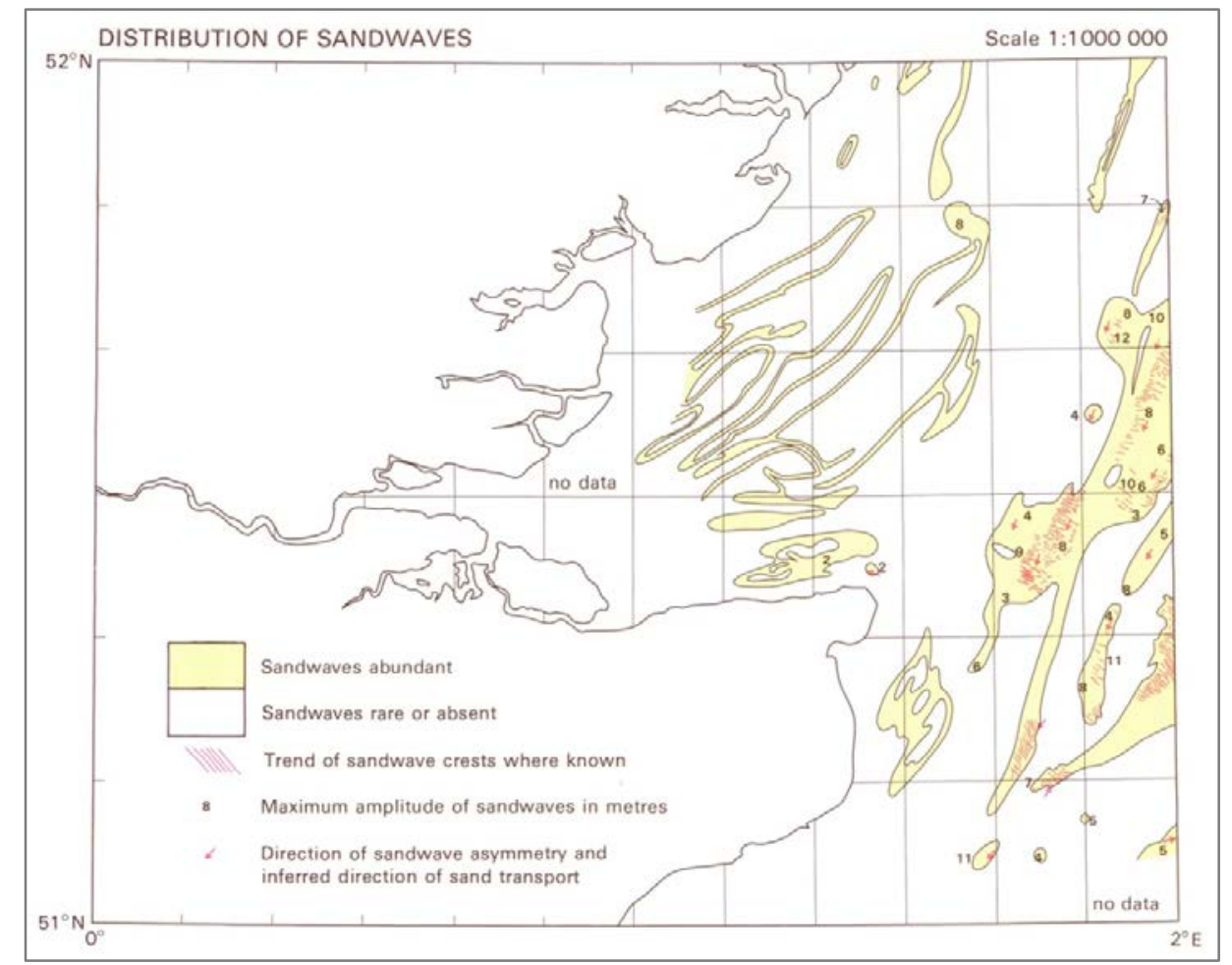

Figure 4. Example of a bedform map taken from the BGS 1:250 000 scale map series (from 1:250 000 Sea Bed sediments and Quaternary geology map for the Thames Estuary; Balson and D'Olier, 1990). 

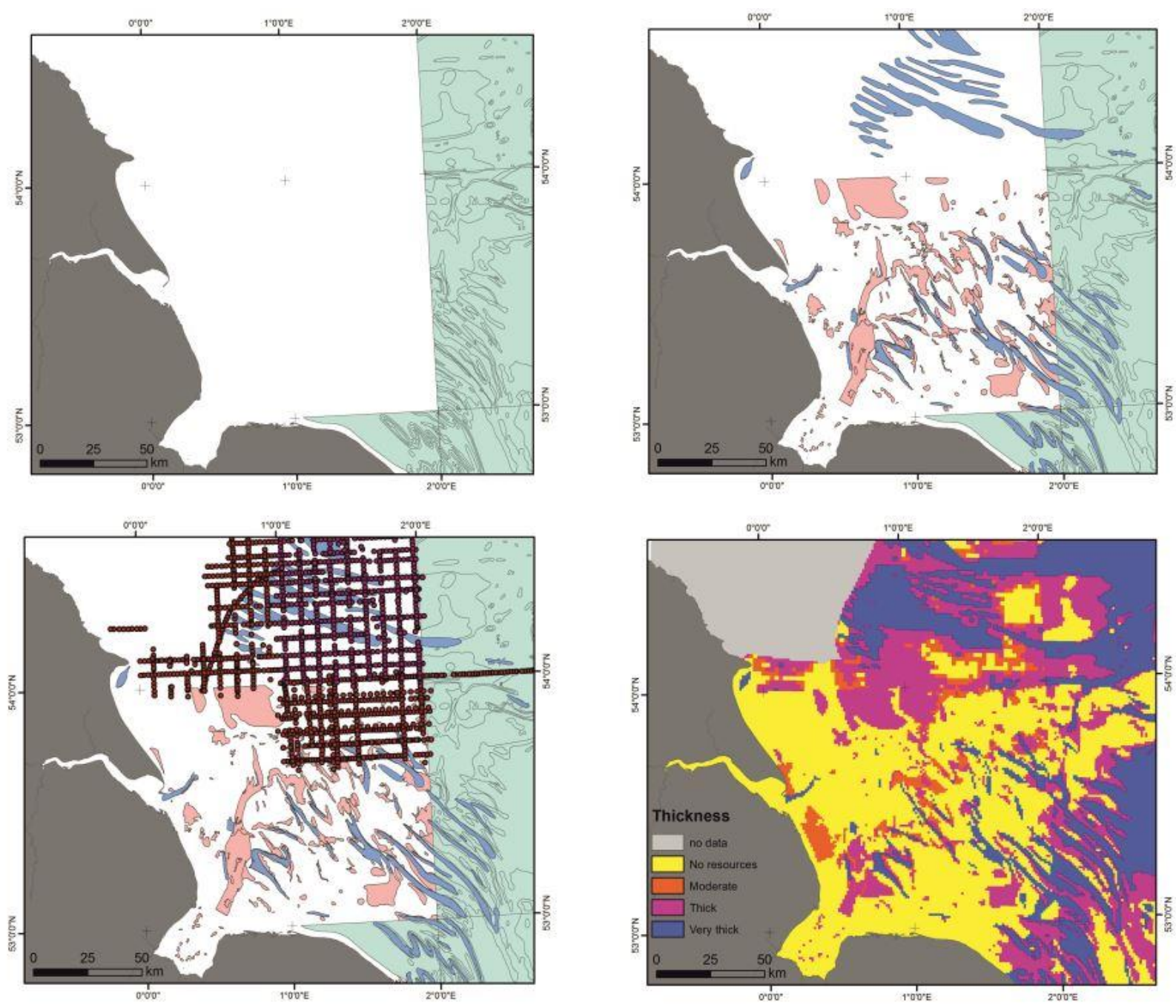

Figure 5. The creation of a resource thickness dataset using Thickness of Holocene sediments (top left), distribution of bedforms (top right), additional data from interpretation of shallow seismic (bottom left), and the final combined and reclassified data that represents total sediment thickness (bottom right).

\section{Step C}

The next step in the process requires information on the physical properties of the sediment. These physical properties were derived from one of the largest and most comprehensive datasets that BGS has access to; the sea bed sample dataset. This comprises data on sediment composition and properties from grabs (Figure 6). 


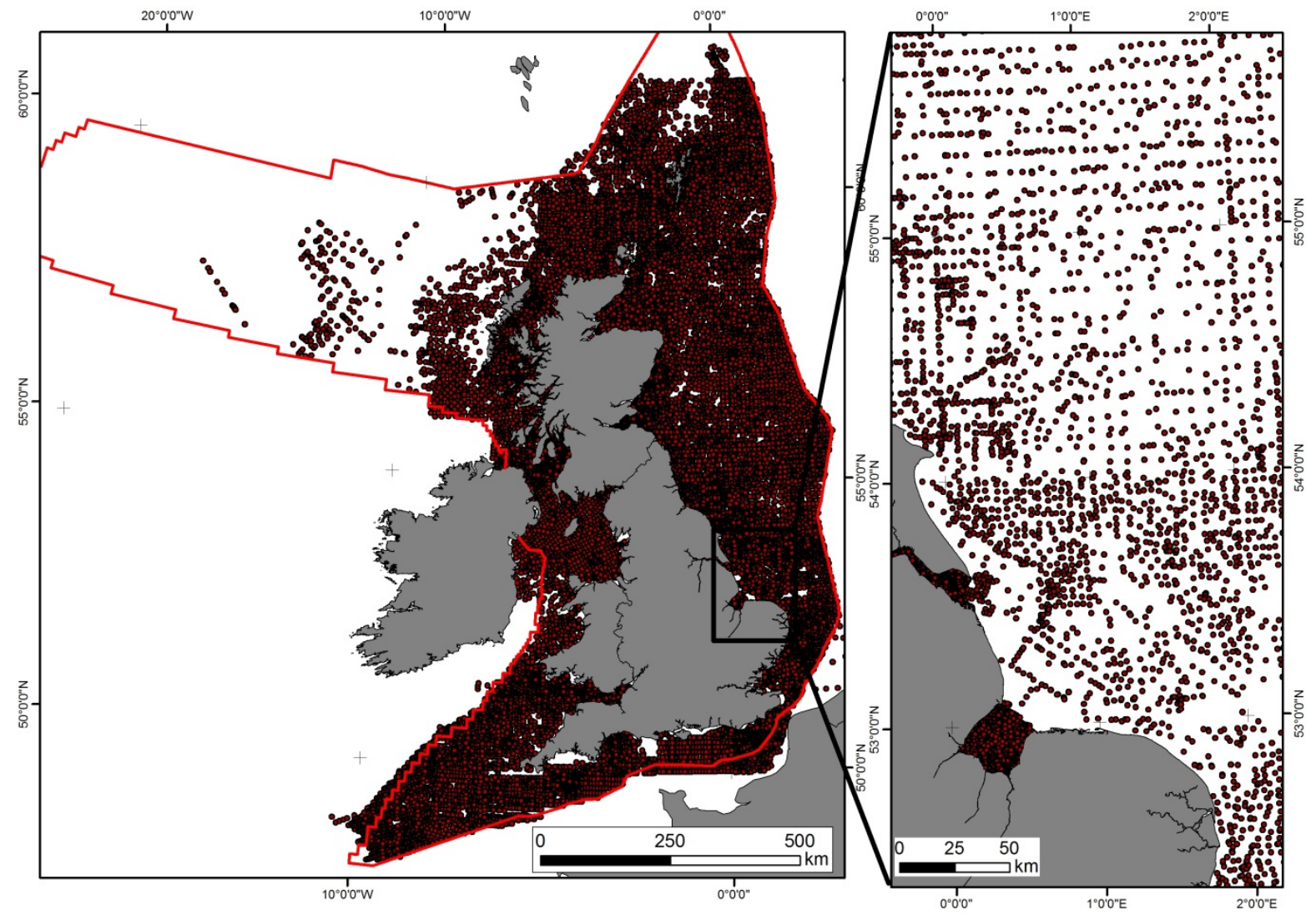

Figure 6. Sample station, with sediment data, coverage held by BGS for the UKCS and inset showing sample density.

To create a dataset with national coverage of sediment parameters, sea bed sample data was interpolated in a GIS Environment. Sample density, on which model outputs were based, varies considerably in different areas. Also, unfortunately, there are data gaps for certain areas. The IDW approach (Figure 7) was therefore utilised due to the variability of the dataset and the speed with which outputs could be generated. As a result of the mixed data coverage, for a national interpolation, the use of a $5 \mathrm{~km}$ cell size for the IDW interpolation is as high a resolution as could realistically be achieved. This resolution does not eliminate the "bull's eye" effect caused by sparse data coverage, but does minimise the effect in areas of dense and moderately dense coverage. As shown by Figure 7 sample density can greatly vary from around 1 sample every $5 \mathrm{~km}$ in the north of the area shown on the inset map to 1 sample every km shown in the central area. The next step was to remove all areas containing sediment that is too fine for use in aggregate applications. This cut-off was defined as any sediment with a mud $(<62.5 \mu \mathrm{m})$ content of over $10 \%$ as not suitable for aggregates. This figure was based on both consultation with industry and fines content used in EN Standards for concrete production. 

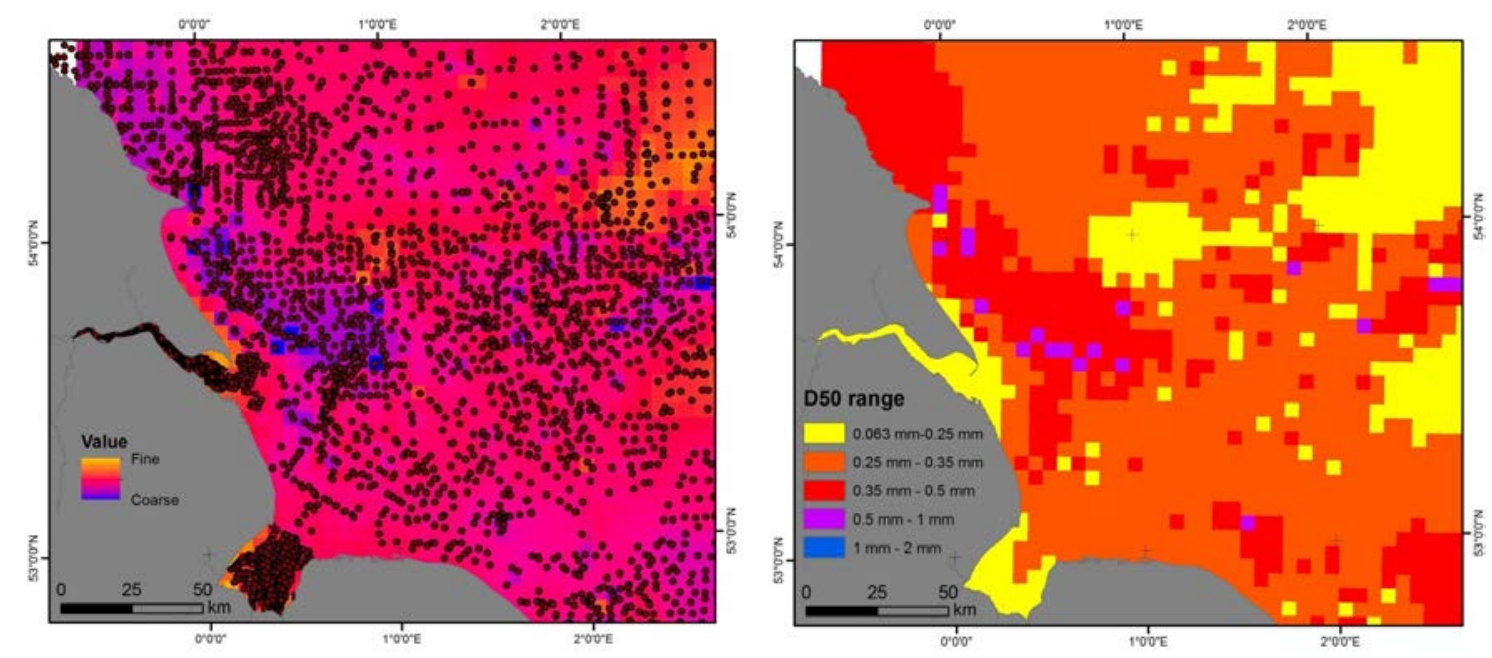

Figure 7. An example of interpolation using IDW for the median grain size (D50) of sand.

\section{Step D}

Steps A-C identified areas of seabed sediment, over 1 metre thick, with less than $10 \%$ fines. These areas all have some potential as aggregate resources, but with no indication of the specification of the resource present. The next step in the process (step D) was to categorise mineral resources. Categorisation is important for the inclusion of this data in the planning process as it shows the importance of resources on a national or regional level and the potential end use. This enables planners to focus on the areas of aggregate resource most in need of protection from other development.

Categorisation involved parameterising the sediment in terms of specifications used by the aggregate industry when considering sand and gravel resources; principally grain size, fines content and carbonate content. Grain size was one of the principal parameters used as this is one of the most important factors when determining the quality and end-use of an aggregate resource. Consultation with industry and relevant European Standards (British Standards Institute, 2002) informed this process and helped to identify relevant cut off values for resource categories.

Following consultation with industry and with reference to the relevant EU standards for construction material, it was decided that a resource would be identified as 'coarse aggregate' if it contained over $10 \%$ lithic gravel. To ensure that gravel-sized biogenic carbonate is not included, as it is not suitable for aggregate applications, the gravel content value represents only the lithic content of the gravel fraction.

Sand resources have been categorised using the median particle diameter of the sand fraction (or D50). The different categories used to define sand resources are shown in Figure 1. 
Areas where the carbonate content of sand exceeds $50 \%$ have also been defined in the UKCS marine sand and gravel maps. This is to highlight the large accumulations of biogenic material in some areas which has implications for the use of sediment for aggregate applications. High carbonate sands are considered to be only suitable for lower specification applications compared to those with a high silica content. A limit of $50 \%$ has been used as this defines the boundary between a carbonate sediment and a siliciclastic sediment. It should be noted that there are no defined carbonate limits in European Standards for aggregate for concreting applications.

\subsection{Geological review}

All areas and categories of sand and gravel resources produced by the GIS modelling process as described in steps A-D were subject to a geological review and, if appropriate, subsequently modified. This was to ensure that model output matches the known geology and geomorphological features. This review of modelled outputs involved incorporating extra information which was not possible to include in the data interpolation and integration steps, such as bathymetric, geophysical and core data. This stage also includes incorporation of information obtained from relevant literature, for example site investigations for renewable energy projects or dredging industry data. This expert review process served to both truth the results of the modelling process and consider whether the modelling process failed to identify areas known to contain aggregate resources due to a lack of input data. The most common changes that were made was to correct for where the surface sediments (used to attribute the properties of aggregate resources) were not representative of sediment at depth. In many cases the surface of the sea bed may not be representative of the underlying thickness of sediment due to the actions of currents; for instance in areas of thin gravel veneer overlying glacial tills. Such geological settings require identification via interpretation of available core logs.

An example of the data shown in a final map output can be seen in Figure 8; this shows the various categories of resources. 


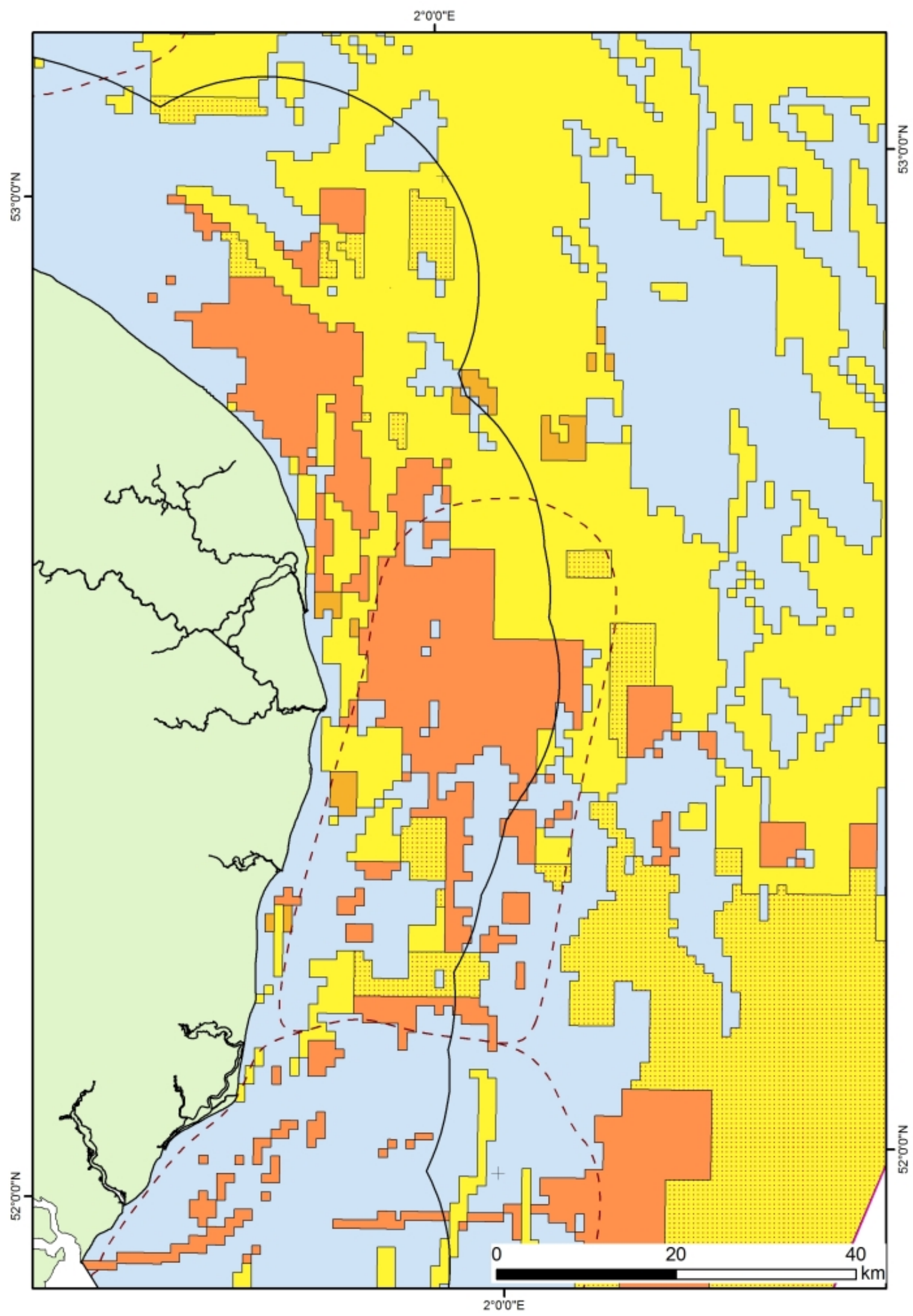

Figure 8. An example of data shown in the map output from the East Coast Onshore and East Coast Offshore planning area. See Figure 1 for a legend. 


\subsection{Limitations}

At the scale of the modelling the level of data available was not sufficient to resolve some areas of complex geology that may contain important marine sand and gravel resources. As a result a separate category identified after geological review was included as 'areas prospective for coarse sand and gravel' (E on Figure 1). These areas relate to geological features, such as palaeochannels or glacial deposits that are known for their geological heterogeneity. These may be prospective for nationally important sand and gravel resources but are unresolvable, especially with the national approach used by this study, with the current levels of data available. Examples of this category include complex glaciofluvial deposits around the Humber area, buried palaeochannels around the Thames Estuary and complex glacial deposits in Liverpool Bay.

It should also be recognised that these maps are not designed to be used for the consideration of the economic potential of individual sites, this can only be proved by a detailed evaluation programme. It is also possible that mineral resources do occur in areas shown on the map as having no resource present due to local variations in geology that are on too small a scale to be resolved by this regional-scale survey.

\section{Discussion - Use of the dataset in UK marine planning}

For effective spatial planning, maps and data, such as produced by this research, are only as good as the planning regime and policies that utilise them. A key issue for offshore minerals, as stated in the Marine Policy Statement, is that minerals must be protected to ensure adequate and secure long term supply (HM Government et al., 2011). This is achieved onshore via the inclusion of mineral safeguarding areas within spatial plans. Mineral safeguarding is an established planning mechanism, which allows for the consideration of mineral resources in the decision making process. As another aim of the UK marine planning process is to better link offshore planning with the well-established onshore system it would seem reasonable that this safeguarding process could also be applied offshore thus meeting the aims of the mineral policy statement.

In the process of mineral safeguarding onshore in England, all resources are considered of equal importance and the same level of protection is afforded to them. This fits in with the principle of mineral safeguarding, in that safeguarded areas are a flag in the planning process and in no way indicate preferential areas for extraction (Wrighton et al., 2011). However, this is not the case in all parts of the UK. In Wales a different approach is taken whereby mineral resources are categorised into resources of national, regional and local importance. This allows for differing policies/levels of protection to be applied to materials most important for growth (Wrighton and Humpage, 2012). The Welsh approach may be the most appropriate to use for marine sand and gravel as very large areas of the UKCS are covered in sands and fine sands. Safeguarding these types of resources is potentially 
unnecessary, as it could detract from the protection of resources which are scarce and require stricter safeguarding policies, such as coarse sand and gravel.

The aggregate resource categories used in the offshore sand and gravel resource dataset have been created in order to be easily interpreted by planners who may have a limited geological background. The maps split all resources into two broad categories, nationally important construction aggregate and regionally important fill-grade material (Figure 1). These two categories have been used as they give an indication as to the relative importance of the resource to the decision maker, potentially allowing for different safeguarding policies/methodologies to be applied to them. Construction-grade aggregate has been further refined into three categories, fine sand, coarse sand and coarse aggregate. This classification gives some indication of the end use and the relative importance of the resources.

The largest current demand for sand and gravel is for coarse sand for use in the manufacture of concrete. These resources face the most restrictions in terms of supply in the immediate future due to high demand by the construction sector and an increasingly restricted supply from onshore resources. Identification of coarse sand as a separate category allows the appropriate level of safeguarding to be applied.

One of the main drivers for the production of these maps was to provide suitable spatial data for regional marine planning for the UKCS. This goal has been achieved and the dataset is now being used by the MMO and Scottish Government in their spatial planning process. Initial planning documents, produced by the $\mathrm{MMO}$, use these data for the depiction of the location of nationally important sand and gravel resources.

The data has been used by the MMO to produce maps of 'areas of future technical opportunity for marine aggregates' in their strategic scoping report and areas of 'optimal aggregate resources' in the East Coast Inshore and East Coast Offshore plan, the first regional plan to be produced (MMO, 2014 and 2013). The maps are accompanied by associated policies regarding the protection of marine sand and gravel resources. The East Coast Inshore and East Coast Offshore draft plan states as one of its policies (Policy AGG3, MMO, 2014) that:

'Within defined areas of high potential aggregate resource proposals should demonstrate in order of preference:

a) That they will not prevent aggregate extraction

b) How, if there are impacts on aggregate extraction, they will minimise or mitigate these

c) How, if the adverse impacts cannot be minimised, they will be mitigated

d) The case for proceeding with the application if it is not possible to minimise or mitigate the impacts.

These policies demonstrate how the data from the marine sand and gravel maps have been incorporated in a mineral safeguarding-type approach to marine spatial planning. The MMO 
have chosen to define their 'areas of high potential aggregate resource' as being those areas identified in the marine sand and gravel dataset as containing coarse aggregate, coarse sand and areas prospective for coarse sand and gravel. These have the most restricted distribution on the UKCS and are most in demand by the construction industry.

\section{Conclusions}

The UK has a wealth of marine aggregate resources and a large aggregate dredging industry which makes a vital contribution to supplying the UK construction sector. To ensure it continues to do so, offshore minerals need to be carefully considered in the new marine planning process.

Changes in planning regulations within the UK which consider the many different uses of marine space have the potential to better manage marine mineral resources. The application of marine spatial planning to the UKCS by the MMO and the acknowledgement of the importance of marine sand and gravel to the UK construction, reclamation and coastal defence sectors will enhance efficient use of, and access to, marine space whilst reducing conflict and ensuring mineral resources are protected.

Access to spatial information, as produced by this research, is vital for sustainable management of offshore mineral resources. Only by having access to this information can we enable both better management of mineral resources and ensure that they are adequately considered in the planning process. The usefulness of such a map has already been proven with its inclusion in the MMO's planning documents and its incorporation into England's marine spatial planning policy. Here the map has been used to define areas of mineral resource for inclusion in the East Inshore and East Offshore Marine Plans. If the map is included in the marine plans for subsequent areas this will provide one of the most detailed national planning policies for aggregates in the marine environment in the world. By effective safeguarding of marine sand and gravel resources we are ensuring that unnecessary sterilisation by other types of development is avoided and future supply of minerals is maintained.

\section{Acknowledgment}

This research was commissioned and funded by The Crown Estate. Evelyn Campbell, Paul Henni and Chloe Wrighton (BGS) are thanked for their valuable contributions and review. The maps and data produced by this research are available online and can be downloaded from http://www.thecrownestate.co.uk/energy-and-infrastructure/downloads/mineralresource-assessments/. This paper is published with permission of the Executive Director of the British Geological Survey (NERC). 


\section{References}

Balson, P.S. and D'Olier, B. 1990, Thames Estuary, Sheet $51^{\circ} \mathrm{N}-00^{\circ}$, Sea bed sediments and Quaternary geology. Map at 1:250 000 scale. Natural Environment Research Council.

Bess, R. 2010. Maintaining a balance between resource utilisation and protection of the marine environment in New Zealand. Marine Policy, 34, pp 690-698.

BGR (Bundesanstalt für Geowissenschaften und Rohstoffe) , LBEG (Landesamt für Bergbau, Energie Und Geologie) and BSH (Bundesamt für Seeschifffahrt und Hydrographie). 2011. Erstellung der digitalen Karten zum thema Verteilung Mineralischer Rohstoffe in der deuschen Nordsee - potenzielle Spülsandvorkommen in Niedersächsischen Küstenraum. Geopotenzial Dueutsche Nordsee Modul B, Dokumentation Nr. 7.

BGR (Bundesanstalt für Geowissenschaften und Rohstoffe) , LBEG (Landesamt für Bergbau, Energie Und Geologie) and BSH (Bundesamt für Seeschifffahrt und Hydrographie). 2013. Erstellung der Karten Zur Verteilung Mineralischer Rohstoffe in der deutschen Nordsee Kiesvorkommen. Geopotenzial Deutsche Nordsee Modul B, Dokumentation Nr. 6.

Bide, T.P., Balson, P.S., Campbell, E. and Green, S. 2013. Marine sand and gravel resources of The United Kingdom Continental Shelf. Map at 1:1 500000 scale. British Geological Survey.

Bide, T.P., Brown, T.J., Idoine, N. and Hobbs, S.F. 2014 United Kingdom Minerals Yearbook 2013. British Geological Survey Open Report. OR/14/036.

British Geological Survey. 2011. DigSBS250, 1:250 000 scale digital data of sea bed sediments on the UKCS. British Geological Survey.

British Standards Institute. 2002. BS EN 12620: 2002+A1:2008: Aggregates for concrete. BSI.

Carneiro, G. 2007. The parallel evolution of ocean and coastal management policies in Portugal. Marine Policy, 31, pp 421-433.

C-SCOPE. 2011. Maritime Spatial Planning (MSP) in Belgium: Analysis of the period 20002011; Coordination Centre on ICZM, Oostende, Belgium 2011.

Department for Communities and Local Government (DCLG). 2012. National Planning Policy Framework. London: HMSO.

Douvere, F. 2008. The importance of marine spatial planning in advancing ecosystem-based sea use management. Marine Policy, 32, pp 762-771.

European Parliament. 2000. Integrated coastal zone management, COM/00/545. Brussels, Commission of the European Communities.

European Parliament. 2007. An integrated Maritime Policy for the European Union (COM/2007/575). Brussels: Commission of the European Communities. 
European Parliament. 2008. Marine strategy framework directive, directive 2008/56 EC of the European Parliament and of the Council of 17 June 2008 establishing a framework for community action in the field of marine environmental policy. Brussels, Commission of the European Communities.

European Parliament. 2012. Blue Growth, Opportunities for marine and maritime sustainable growth. Communication from the commission to the European Parliament, the Council, The European Economic and Social Committee and the Committee of the Regions. Com/2012/0494 final/. Brussels, Commission of the European Communities.

European Parliament. 2014. Directive on Maritime Spatial Planning, Directive 2014/89/EU. Brussels, Commission of the European Communities.

Folk, R.L. 1954. The distinction between grain size and mineral composition in sedimentary rock nomenclature. Journal of Geology 62, 344-359.

HM Government. 2009. Marine and Coastal Access Act 2009. HM Government.

HM Government, Northern Ireland Executive, Scottish Government and Welsh Assembly Government. 2011. UK Marine Policy Statement. HM Government.

Hull, A. 2013. Managing competition for marine space using the tools of planning in the UK. Planning, practice and research, 28, pp 503-526.

IFREMER. 2007. Inventair des resources en Matériaux Marins. IFREMER. (Available to view as a Web Mapping Service at http://sextant.ifremer.fr/fr/web/granulatsmarins/geoviewer?url=https://www.ifremer.fr/sextant doc/granulats marins/contexte/Nat ionalisation/Geol National.xml) (accessed January 2015).

MMO (Marine Management Organisation). 2014. East Inshore and East Offshore marine Plans (April 2014). Marine Management Organisation.

MMO (Marine Management Organisation). 2013. Strategic Scoping Report for marine planning in England (August 2013). Marine Management Organisation.

National Ocean Council. 2013. National Ocean Policy implementation Plan. National Ocean Council.

National Oceanic and Atmospheric Administration (NOAA). 2014. Regional Activities. Available at http://cmsp.noaa.gov/activities/ (accessed on 28/6/14).

Newell, R and Woodcock T. 2013. Aggregate dredging and the marine environment: an overview of recent research and current industry practice. The Crown Estate.

PERC. 2013. Pan European standard for reporting of exploration results, mineral resources and reserves. The Pan European reserves and resources reporting committee, revision 2:29 November 2013. 
Scottish Government. 2010. Marine (Scotland) Act 2010. Scottish Government.

Scottish Government. 2015. Scotland's National Marine Plan. Scottish Government.

The Crown Estate. 2014. Marine Aggregates capability and Portfolio 2012. The Crown Estate.

TNO (Nederlandse Organisatie voor Toegepast Natuurwetenschappelijk Onderzoek) 2012. Multiple querying of geological databases to visualise offshore sand resources in the Netherlands part of the North Sea. TNO report number R10097.

US Government. 2010. Executive order 13457 Stewardship of the Ocean, Our Coasts, and the Great Lakes. US Government

Wrighton, C.E. and Humpage, A.J. 2012. Aggregate safeguarding maps of Wales. British Geological Survey Commissioned Report, CR/12/039.

Wrighton, C. E., McEvoy, F. M. and Bust, R. 2011. Mineral safeguarding in England: good practice advice. British Geological Survey Open Report OR/11/046. 53pp. 